\title{
Jacek Kopciński
}

Instytut Badań Literackich PAN

\section{NOWE PRZESTRZENIE SUBIEKTYWNOŚCI Radiowy genotyp dramaturgii współczesnej}

\section{ENIGMATYCZNE POLILOGI}

Od co najmniej piętnastu lat w polskiej dramaturgii współczesnej zauważalna jest tendencja do rozluźniania struktury dramatycznej i rezygnacji z konwencjonalnej organizacji tekstu. Tradycyjny podział na akty i sceny już dawno został zarzucony, ze sztuk znikają też didaskalia, a nawet imiona postaci. Dla wyróżnienia nadawców wypowiedzi autorzy stosują enigmatyczne nazwy lub zupełnie umowne znaki: litery, liczby, symbole na klawiaturze komputerowej, a niekiedy jedynie różne kroje czcionek. Zdarza się, że zmianę w wewnętrznym procesie komunikacyjnym sygnalizują półpauzą, jak w utworze epickim, a czasem dialog kilku postaci zlewa się w jeden anonimowy, eliptyczny i wielce syntetyczny polilog. W najnowszym dramacie Mariusza Bielińskiego Ojcze nasz natrafiamy na taki oto zapis akcji dramatycznej:

proszę czekać na wezwanie, kiedy zostaniemy przyjęci, proszę czekać na wezwanie, ale przecież byli państwo wczoraj, tu są konsultacje, przecież są nowoczesne metody, tak, ale trzeba się zakwalifikować, mamy wszystkie wyniki, a przebieg leczenia, wycinki, może dałoby się zakwalifikować gdyby zdobyć wycinki, tam gdzie była robiona histopatologia, ja to zdobędę, jutro pojadę, powinni mieć, i wtedy co, wtedy podejmiecie leczenie, jeśli pacjent przejdzie kwalifikację, pojadę jeszcze dzisiaj, wszystko zależy od, można będzie, a nie, nie, no nie, ile pacjent ma lat, no tak, ogólny stan zdrowia, no nie, ogólny stan zdrowia nie pozwoli, ale jak to, tu są konkretne, to co to już, tu są konkrety, to już, tak, to możemy już iść, naświetlenia możemy zrobić, jakie naświetlenia, tu na miejscu, przez pięć dni, codziennie trzeba przyjeżdżać, codziennie przyjeżdżać, przez pięć dni, aha, mogę jeszcze na chwile pani doktor, tak, proszę, po tych naświetleniach jakaś kontrola, jaka kontrola, to po co te naświetlenia, tyle mogę zrobić, aha, aha, pani doktor, tak, ile to potrwa, pięć dni, nie o to pytam, nie wiem, nie wiem, rozumiem, karetka pana zabierze, każdego dnia, przywiezie i odwiezie, rozumie pan, rozumiem, rozumiem, to ile to dni, pięć, to ile to dni, cztery, to ile do dni, jeszcze tylko jutro, to ile to dni, już nie, już nie, a to i dobrze, bo już nigdzie nie pojadę, nie chcę, nigdzie już nie pojadę, tato, nie. ${ }^{1}$

\footnotetext{
1 M. Bieliński, Ojcze nasz, „Dialog” 2019 nr 7-8.
} 
Bieliński nie jest odosobniony w eksperymentalnym podejściu do poetyki dramatu. Powstają utwory, których najważniejszym bohaterem zdaje się być sam dyskurs, uwolniony spod reżimu tekstowej struktury i organizacji. Dialogi i monologi mieszają się ze sobą, tworząc nowe, zróżnicowane formy wypowiedzi pośrednich, których źródłem - nadawcami - nie są wyłącznie postacie dramatu, niekiedy ukryte za słowami, ale także otaczające ich urządzenia, jak smartfon, radio, telewizja, komputer. Dramaturgii w nowych tekstach nie budują już wyłącznie rozmowy bohaterów czy ich wyznania, ale wiele innych przekazów, najczęściej zasłyszanych, jak wiadomości w poczekalni dworcowej, piosenka za oknem, reklama sącząca się z głośników w sklepie. Zapisywane w postaci językowego streamingu tekstowe kolaże, montaże, hybrydy stają się sporym wyzwaniem dla czytelników. Współcześnie, aby odczytać, pojąć i zinterpretować dramat, sami musimy go sobie zorganizować, odnaleźć w nim jakiś wewnętrzny porządek, nadać mu jakąś domyślną strukturę. Strategie, jakie stosujemy, by plan wyrażania uczynić w dramacie bardziej klarownym, a sam tekst - zrozumiałym, polegają zwykle na odniesieniu utworu do znanych systemów gatunkowych: literackich, teatralnych, a współcześnie - medialnych. W środku słońca gromadzi się popiół Artura Pałygi, jeden z najbardziej zagadkowych tekstów, jakie zdarzyło mi się czytać, zestawiamy z awangardowym poematem lingwistycznym i internetowym hipertekstem $z$ jednej strony $i$ estetyką teatru postdramatycznego $\mathrm{z}$ drugiej. $\mathrm{W}$ ten sposób, dla zapanowania nad zaskakującym fenotypem dramatu, który nazwałem kiedyś „kłączem”, „siecią”, „rozlewiskiem słów"2, ustanawiamy dla niego gatunkowy genotyp.

Tekst pozbawiony wyrazistej struktury zdaje się ewokować równie płynną i chaotyczną rzeczywistości, ale uważna lektura takich utworów, jak Ojcze nasz nakazuje pod tym względem interpretacyjną ostrożność. Mamy raczej do czynienia $\mathrm{z}$ efektem założonej nieokreśloności, obejmującym takie podstawowe kategorie, jak czas, przestrzeń, świat przedstawiony, okoliczności działania postaci, ich tożsamość, status ontologiczny, charakter zdarzeń, i decydującym o metaforycznym kształcie rysującej się w utworach akcji dramatycznej. „Akcja toczy się w ciągu jednej nocy w czasie teraźniejszym złożonym. Miejsce podlega entropii, aż do sceny Wyprowadzenia". ${ }^{3}$ - czytamy w didaskaliach do Zimnego bufetu Zyty Rudzkiej. Bohaterką swojej sztuki pisarka uczyniła „Śmiercionośną laleczkę”, reprezentowaną przez trzy osoby dramatu: Matrionę, Matriochę i Matrioszkę, będące pośmiertną emanacją zmarłej kobiety w jej trzech fazach życia, a zaistniałej w umysłach czuwających przy jej ciele, dorosłych już dzieci.

$\mathrm{Z}$ kolei w dramacie Pałygi $W$ środku stońca ... kształt świata przedstawionego opisują dwie postacie będące emanacją myśli głównej bohaterki Lucy, która zmarła, Iskierka i Płomyk:

2 J. Kopciński, Dziwny przystanek, [w:], idem, Wybudzanie. Dramat polski. Interpretacje, Warszawa 2018, s. 75. gnd.art.pl.

Z. Rudzka, Zimny bufet, tekst udostępniony na stronie Gdyńskiej Nagrody Dramaturgicznej 
LUCY

gdziejes

gdziejestem

ISKIERKA

w małym bardzo małym

PŁOMYK

w dużym bardzo dużym

ISKIERKA

to punkt jesteś w punkcie

PŁOMYK

w punkcie wyjścia

ISKIERKA

dojścia

PŁOMYK

jest południe to jest punkt południe

ISKIERKA

W schronie po końcu świata kiedy wszystko jest już wyłączone

[...]

ISKIERKA

nadajemy audycję ze schronu z pomieszczenia bez drzwi i bez okien bez wyjścia

PŁOMYK

z punktu wszystkiego widzenia

$[\ldots]$

ISKIERKA

nadajemy ostatnie słuchowisko świata ${ }^{4}$

Natomiast w dramacie Feinweinblein Weroniki Murek inicjalny dialog naśladuje format dawnej reklamy radiowej. Absurdalny komunikat wybrzmiewa w pokoju bohaterów, którzy stroją radio, i zapowiada równie absurdalny, choć ukrywający groźną tajemnicę, tok ich rozmów:

Ciemno. Szum radia: ktoś kręcac gałka szuka odpowiedniego programu.

Gtupawa melodyjka, niby to w cyrku czy lunaparku

GŁOS DZIECKA

Jest jedno lekarstwo na śmierć: liście polnej babki.

GŁOS KOBIETY

Zwilżyć lekko, a potem nacierać, nacierać.

Glupawa melodyjka: cyrk albo lunapark.

GŁOS KOBIETY 2

Jest czwarta: chwila przyjemności.

4 A. Pałyga, $W$ środku stońca gromadzi się popiót, [w:] idem, Powrót bogów, Kraków 2017, s. $99-100$. 
Psikanie: sprej albo flakon.

GŁOS KOBIETY 2

Woda perfumowana, kiedyś w każdym domu.

Glupawa melodyjka: cyrk albo lunapark.

GŁOS MĘŻCZYZNY 1

Wysłuchaliśmy właśnie Westchnienie Szebalina.

GŁOS MĘŻCZYZNY 2

A teraz wracamy na linię naszych rozmów. ${ }^{5}$

Nieskonwencjonalizowany zapis interesujących nas utworów zdradza także obecność podmiotu dramatycznego, który w sposób wysoce subiektywny kształtuje dostęp do świata bohaterów dramatu. ${ }^{6}$ Tak mianowicie, jakby wyłącznie rejestrował ich głosy, na różne sposoby wybrzmiewające w odrębnych przestrzeniach i w zmieniającym się czasie. ${ }^{7}$ Zapisane, głosy te domagają się od czytelników dramatu precyzyjnej selekcji, która jest pierwszym krokiem do rozpoznania mówiących, sytuacji, w jakiej się znaleźli, sensu ich wypowiedzi, charakteru ich działań, kształtu zdarzeń itd. Usłysz, odróżnij, wyobraź sobie, śledź zmiany, rekonstruuj metaforyczny sens - właśnie taka dyrektywa odbiorcza dominuje w nowym dramacie. Nie jest on wyłącznie „tekstem dla teatru”, tj. nieustrukturyzowanym materiałem językowym, który, niczym światło, muzyka, dźwięk, głos i ruch aktorów dopiero na scenie znajduje swoją formę, funkcję i znaczenie. ${ }^{8}$ Przeciwnie, kryje on własną strukturę tekstową, sens i sobie właściwy projekt wykonawczy, który rewolucjonizuje spektakl teatralny, ale wywodzi się ze studia radiowego, co przekornie sygnalizują niektórzy autorzy tych enigmatycznych sztuk.

Spektakle realizowane na podstawie nowej dramaturgii bardzo często przypominają koncert, występ estradowy czy telewizyjne show, a podstawowym rekwizytem w tych inscenizacjach jest mikrofon. Można go traktować jak znak szczególny teatru postdramatycznego, w którym bezpośredni kontakt aktorów z publicznością pozostaje ważniejszy od kreacji fikcyjnego świata. Można - jako symbol nowej rzeczywistości medialnej, która dla ludzi współczesnych stała się środowiskiem naturalnym. Najważniejszą cechą zmediatyzowanego świata jest jego wirtualność i wielokanałowość, która sprawia, że podłączeni do wielu różnych źródeł obrazów i dźwięków nieustannie przekraczamy granice miejsca i czasu. ${ }^{9}$ Niewielki smartfon daje nam nie tyko możliwość jednoczesnego kontaktu z ludźmi na całym świecie, ale także nieustannego penetrowania cyfrowych zasobów sieci, na które składają się

5 W. Murek, Feinweinblein. Dramaty, Wołowiec 2019, s. 7.

6 J. Kopciński, Podmiot w nowym dramacie - ponad głowami bohaterów, Warszawa 2014, s. $180-197$.

7 Por. E. Wąchocka, Solo na głosy, [...] Świat (w) polskiej dramaturgii najnowszej. W lekturze i na scenie. W radiu, red. J. Kopciński, Warszawa 2016.

8 M. Sugiera, Performatywy, performanse i tekst dla teatru, „Didaskalia” $2010 \mathrm{nr} 99$.

9 H. Jenkins, Kultura konwergencji. Zderzenie starych i nowych mediów, przekł. M. Bernatowicz, M. Filiciak, Warszawa 2007. 
telewizyjne relacje na żywo, historyczne archiwa, dziennikarska dokumentalistyka, artystyczna fikcja, internetowy hipertekst. Mikrofon ustawiony na scenie ma nam przywrócić poczucie realności scenicznego zdarzenia, jednak czy nie stanowi on jeszcze jednego źródła sygnałów docierających do nas poprzez system głośników? Czy intymny kontakt aktorów z widzami nie odbywa się dziś za pośrednictwem mikroportów, precyzyjnie ustawianych i sterowanych przez inżynierów dźwięku, którzy nowe metody nagrań i transmisji testują na co dzień w studiach rozgłośni radiowych? Spektakl współczesny stanowi część systemu kultury medialnej i brzmi jak słuchowisko. Zdarza się także, że widzowie teatralni zostają zaopatrzeni w słuchawki, by lepiej usłyszeć wszystkie kanały, którymi docierają do nich głosy aktorów, wymieszane z generowanymi dźwiękami i muzyką.

Przykładem Wieloryb. The Globe zrealizowany przez Ewę Rysovą na podstawie tekstu Mateusza Pakuły w Łaźni Nowej (prem. 2016) czy Strach Roberta Bolesto w reżyserii Małgorzaty Wdowik w TR Warszawa (prem. 2018). Z chwilą, gdy widzowie zamieniają się w słuchaczy, percepcja widowiska radykalnie się zmienia. Na stronie TR Warszawa czytamy:

Spektakl Małgorzaty Wdowik i zespołu czerpie inspiracje z klasycznego kina grozy, jednocześnie kreując własny, niepowtarzalny świat, w którym pierwotne lęki spotykają się z najnowszymi technologiami. Dzięki nowatorskiemu użyciu dźwięku widz może zanurzyć się w świecie sennego koszmaru wykreowanego na scenie.

Strach to próba dotarcia do źródeł naszych własnych lęków. Twórcy szukają ich w opowieściach ludowych i popkulturowych, we wspomnieniach rodzinnych i doświadczeniach politycznych. Budują z nich rzeczywistość między fantazją a snem, w której najważniejsza staje się walka o swój strach. Jeśli wiesz, że gdzieś tam mieszka przerażające COŚ, to nie dajesz się oszukiwać. Kontrolujesz zamiast być kontrolowanym. Sam decydujesz, kto rządzi strachem. Nie bój się bać!10

Doprowadzony bezpośrednio do uszu odbiorcy dźwięk daje złudzenie bezpośredniego uczestniczenia $\mathrm{w}$ heterogenicznej rzeczywistości wykreowanej na scenie i przeżywania zdarzeń zewnętrznych inaczej niż w teatrze, a mianowicie jak odbicia wewnętrznych doświadczeń postaci ${ }^{11}$ - podczas gdy dostępny dla oczu sceniczny obraz pozostaje wyłącznie ich reprezentacją. Strach to w gruncie rzeczy projekt słuchowiska realizowanego na żywo z możliwością podglądania podsłuchiwanych bohaterów, co dla niektórych widzów było zbędnym dodatkiem. ${ }^{12}$ Twórcy tego spektaklu wykorzystali nowoczesną technologię, apelując do zmediatyzowanej wyobraźni odbiorców po to przede wszystkim, by za sprawą dźwięków zmienić na chwilę ich typowy sposób percepcji rzeczywistości i dać im poczucie zmysłowego ,zanurzenia” w świecie o zmienionych, a nawet zniesionych granicach ontologicznych.

$10 \quad$ trwarszawa.pl/spektakle/strach.

11 J. Limon, Trzy teatry: scena telewizja radio, Gdańsk 2003, s. 152.

12 Opinię taką wyraził Wojciech Baluch podczas konferencji „,Gatunki dramatyczne/Rekonfiguracje”, zorganizowanej przez Uniwersytet Śląski oraz Instytut Badań Literackich PAN, Warszawa 2019. 
Podobnie było w przypadku Wieloryba. The Globe Rysovej i Pakuły, gdzie emisja dźwięku w słuchawkach pozwalała odbiorcom wejść w świat odczuć i wyobraźni człowieka dotkniętego afazją:

Różnica między chorym na afazję i nie - polega na ilości bodźców, które odbieramy. Afatyk doświadcza świata o wiele intensywniej, jego organizm zmuszony jest reagować częściej i mocniej. Dlatego trudniej jest mu się skupiać, obciążony tymi bodźcami raczej odcina się od świata, ale to nie jest otępienie ludzi z alzheimerem. Afatyk to człowiek o niezwykłej wrażliwości, który żyje w pewnym chaosie, czasami bardzo męczącym, na dodatek nie potrafi się podzielić swoimi wrażeniami, przez co często czuje się samotny. Właśnie o tym chcieliśmy opowiedzieć ${ }^{13}$

- tłumaczy Ewa Rysova, reżyserka przedstawienia.

Główną rolę wieloryba wyrzuconego na brzeg zagrał w tym wyjątkowym spektaklu Krzysztof Globisz, aktor do dzisiaj zmagający się ze skutkami wylewu krwi do mózgu. „Bywa, że odczuwam wszystko” 14 - mówił z niejakim trudem aktor, a widzowie/słuchacze, poddawani działaniu naturalnej muzyki wielorybiego nawoływania, dzielili z nim to niesamowite, choć zarazem trudne do zniesienia doświadczenie.

Technologia Strachu i Wieloryba wymagałaby bardziej precyzyjnego opisu, dla nas jednak najważniejsze jest fakt, że literacką podstawą obu przedstawień były dramaty o kształcie tekstowych hybryd i kolaży, które w wyniku głosowo-dźwiękowej realizacji porządkowały się strukturalnie i dookreślały w zakresie ontologii świata przedstawionego. Tę samą właściwość zauważam w wielu innych utworach dramatycznych doby obecnej. Przytoczony fragment Ojcze nasz przestaje być dla nas tak enigmatyczny, gdy spojrzymy na niego jak na językową matrycę współczesnej komunikacji medialnej, syntetyczny zapis bardzo osobistego doświadczenia, a zarazem tekst przeznaczony dla radia. Genotyp orientuje fenotyp i oto w eliptycznym polilogu Bielińskiego „słyszymy” szpitalną fonosferę „rejestrowaną” przez jednego z uczestników zdarzeń, której tematem dominującym jest choroba ojca, motywem ukrytym napięcie między ojcem i troszczącym się o niego synem, a emocją przenikającą całość zapisu - niezgoda obu mężczyzn na śmierć. W tekstowym strumieniu dramatopisarz zawarł sceny rozgrywające się w izbie przyjęć i gabinecie lekarskim między czterema postaciami, a także kilka krótkich interakcji domowych, w których słyszymy głosy ojca i syna, następujących po sobie w rytmie upływającego czasu, dzień po dniu, aż do skończenia krótkiej kuracji chorego. ${ }^{15} \mathrm{~W}$ słuchawkach te momentalne zmiany planów przestrzennych i czasowych, tak charakterystyczne dla słuchowiska, przyjmują postać dynamicznego reportażu z wyprawy do szpitala. Za sprawą nowej technologii 5.1, sytuującej słuchacza w samym środku akcji, będzie to reportaż uczestniczący. s. $17-18$.

13 Zgoda na większa wrażliwość. Z Eva Rysowa rozmawia Jacek Kopciński, „Teatr” $2018 \mathrm{nr} 1$

14 M. Pakuła, Wieloryb. The Globe, Kraków 2016 s. 43.

15 Dokładniej analizuję ten utwór w szkicu Metafizyczne dolby surround, „Dialog” 2019 nr 7-8. 


\section{DŹWIĘKOWISKO}

Ojcze nasz, podobnie jak Zimny bufet, W stodku stońca gromadzi się popiót czy Feinweinblein, ukrywa projekt słuchowiska przestrzennego nagranego w systemie 5.1, które w nadzwyczajny sposób intensyfikuje doznania odbiorców tradycyjnego słuchowiska wyprodukowanego w systemie stereo. Nowa technologia skłoniła kilku zdolnych autorów (a często także reżyserów) do stałej współpracy z teatrem radiowym. Krzysztof Czeczot (Dublin one way, Andy), Tomasz Man (Moja ABBA, Sex machine, Hiob, Mojżesz), Dariusz Błaszczyk (Pasażer Luter), a ostatnio Krzysztof Bizio $\left(\mathrm{O}_{-} 2 \mathrm{O}\right)$ tworzą dziś dramaty radiowe o zupełnie nowym kształcie, zaskakująco bliskim strukturze cytowanych wcześniej tekstów - formalnie nie przypisywanych do tej konwencji gatunkowej. Realizatorem większości nowatorskich słuchowisk w Polskim Radiu jest Andrzej Brzoska, inżynier dźwięku i artysta obdarzony fenomenalną wyobraźnią dźwiękową. Tytuł przełomowego dla nowej dramaturgii radiowej słuchowiska Andy Krzysztofa Czeczota to czytelna aluzja do osoby tego uzdolnionego inżyniera i artysty:

Dzięki uważnej obserwacji postępów cyfrowych w takich rozgłośniach jak BBC uznany w Polsce realizator dźwięku, Andrzej Brzoska, wprowadził do repertuaru polskiej radiofonii spektakle w nowym systemie, do którego odsłuchu odbiorca musi posiadać kino domowe z włączonym dekoderem dźwięku Dolby Pro Logic 2. Lewy, prawy, tylny lewy, tylny prawy i centralny - w takiej konfiguracji kierunkowej rozchodzi się głos aktora i muzyka. Pięć źródeł dźwięku otworzyło zupełnie nowe możliwości twórcom radia. Mowa o dźwięku wielokanałowym, w której to technologii za każdy „kanał” odpowiadać będzie kolejny głośnik (akcja rozgrywa się „dookoła” głowy słuchacza). Głos aktora może pojawić się w tylnym prawym głośniku, by za chwilę zniknąć i odezwać się w przednim lewym. ${ }^{16}$

Inspiracją dla pionierów słuchowiska przestrzennego była kinowa technologia Dolby Surround, zaadaptowana do warunków radiowych. W kinie głośnik centralny służy emisji dialogów, głośniki boczne przednie emitują dźwięki sygnalizujące ruch osób, zwierząt czy maszyn, natomiast głośniki tylne przeznaczone są do efektów specjalnych. Radio znacznie modyfikuje ten schemat, za pomocą pięciu głośników i jednego subwoofera (stąd liczbowe oznaczenie systemu), tworząc wokół słuchacza niezwykłe obrazy dźwiękowe. Słuchowiska nagrywane w systemie 5.1 realizuje się w przestronnych studiach, w których aktorzy mogą się poruszać jak na scenie, co zasadniczo zmienia możliwości głosowej interpretacji wypowiadanego przez nich tekstu. Wypowiedzi aktorów rejestrują liczne, czułe, połączone ze sobą mikrofony, ustawione w różnych miejscach studia. Dzięki dźwiękowym ekranom mikrofony nie zapisują wszystkich sygnałów, jednak wiele $\mathrm{z}$ nich „zbiera” ten sam sygnał dobiegający z różnych odległości, a więc

16 J. Łastowiecki, Dźwięk przestrzenny jako ekwiwalent misyjnego i komercyjnego modelu artystycznych produkcji audialnych, ,Media, kultura, komunikacja społeczna” 2014 nr 1, s. 65. 
w innym czasie, i właśnie ten efekt pozwala później wywołać w słuchaczach poczucie przemieszczania się bohaterów w przestrzeni. Aktorzy mogą także na różne sposoby pracować z mikrofonami, mówiąc do nich z bliska i z daleka, z góry, $\mathrm{z}$ dołu, stojąc centralnie między kilkoma mikrofonami, i znajdując się gdzieś na uboczu, w zasięgu jednego z nich. Dzięki takiej technice w przyszłym słuchowisku można kształtować różne plany akustyczne w sposób naturalny, nie tylko poprzez montowanie dźwięków nagranych osobno, ale poprzez reżyserię strumienia dźwięków „zebranych” w jednej przestrzeni.

Mojżesz. Remiks Tomasza Mana (prem. 2018) został nagrany w systemie stereo, ale nosi ślady nowatorskiego podejścia do sesji nagraniowej w studio radiowym. W słuchowisku słychać bowiem reżyserskie komentarze do realizowanej wcześniej audycji. Mojżesza i Aarona zagrali Andrzej Chyra i Mirosław Zbrojewicz. W części pierwszej obaj aktorzy siedzą w fotelach przy mikrofonach, w części drugiej stają przy nich, a w części trzeciej jeden z nich kładzie się na podłodze, drugi zaś towarzyszy mu pochylony nad ciałem partnera. Ustawienie mikrofonów dostosowane jest do układu ciał wykonawców. Zarejestrowaną rozmowę reżysera $\mathrm{z}$ dwoma aktorami odsłuchuję $\mathrm{z}$ nagrania i zapisuję $\mathrm{w}$ formie dramatycznego polilogu, który odsłania radiowe kulisy:

tutaj musicie leżeć przepraszam starość wiesz starość ok. Andrzej leży ja siedzę przy łóżku on umiera kroplówka rozumiesz taka metafora a nie chciałbyś się położyć mogę się położyć i macie dwa kanały dobra sytuacja jest taka że z niego już nic nie będzie zostanę tylko ja ciebie nie ma ty już umarłeś rozumiesz przyjechałeś do niego i mówisz mu prawdę ty wszystko stary rozpier... cały świat od tej pory wszyscy się będą napier... w tym Izraelu do końca świata już tak będzie ty mu mówisz prawdę a skąd ja to wiem bo jesteś już po tamtej stronie ano tak bo masz to napisane... ${ }^{17}$

Po tej wymianie myśli aktorzy zaczynają czytać tekst i wyraźnie słychać, że głos leżącego Chyry, jest o wiele bardziej zduszony niż siedzącego Zbrojewicza, wydobywa się z dołu, naznaczony jest fizyczną słabością bohatera i ewokuje jego duchowy upadek. Głos drugiego aktora brzmi czyściej i silniej, nie jest obciążony ani zmęczeniem, ani emocjami, to głos obiektywny, sygnalizujący odmienny status ontologiczny bohatera - w lekturze poetyckiego dramatu Mana możliwy do uchwycenia tylko poprzez wnikliwą analizę świadomości postaci.

Dźwięk w słuchowisku przestrzennym może zostać przetworzony lub uzupełniony rozmaitymi efektami, sygnalizującymi metamorfozę świata przedstawionego i jego mieszkańców: w sen, marzenie, wspomnienie, rzeczywistość fantastyczną lub transcendentną. Może także przekształcać się w mozaikę dźwięków realnych, nagranych w świecie rzeczywistym odgłosów łąki czy kawiarni, dźwięków wygenerowanych przez program komputerowy, zagranych

17 Mojżesz. Remiks Tomasza Mana, reż. autora, prem. słuchowiska w Trzecim Programie PR 12 VIII 2016. 
na instrumentach, wydobytych ze zwykłych przedmiotów czy urządzeń, a następnie skomponowanych w jedną całość na zasadzie „plam dźwiękowych” $\mathrm{w}$ muzycznym ambiencie. ${ }^{18}$ Istotą i funkcją nowej technologii w teatrze radiowym jest maksymalne zaangażowanie odbiorcy, wywołanie w nim wrażenia przebywania w miejscu akcji i odczucia fizycznej bliskości postaci dramatu. W nagraniu stereo istnieją one jak na niewidzialnej scenie, w nagraniu 5.1 zdają się otaczać słuchacza, a ich obecność odczuwana jest jako zupełnie realna - niczym obecność ludzi zamkniętych w jednym, ciemnym pomieszczeniu. Efekt tego rodzaju wzmacnia intymność słuchowiskowego przekazu i tworzy złudzenie prawdziwego kontaktu z bohaterami, wśród których niekiedy pojawiają się osoby autentyczne, przywołane czy uobecnione za pośrednictwem archiwalnych nagrań radiowych. Gdy osoba taka nie żyje, spotkanie z nią w dźwiękowej kapsule wywołuje niebywały efekt, o czym za chwilę. Inżynierowie dźwięku stosują także nagranie binauralne, dokonywane za pomocą mikrofonów umieszczonych w małżowinach usznych makiety ludzkiej głowy, ustawionej w studiu radiowym. Mikrofony takie zbierają i selekcjonują dźwięki dokładnie tak, jak czyni ludzkie ucho, co jeszcze potęguje wrażenie uczestnictwa w kreowanych sytuacjach.

System przestrzenny wykorzystywany jest do realizacji słuchowisk opartych na tekstach nowych, ale i klasycznych, poddanych specjalnej reżyserii. W 2011 Andrzej Brzoska pracował nad Hamletem Williama Shakespeare'a. „Przyjęto założenie, że system dźwięku przestrzennego pozwoli na ciekawe wykreowanie atmosfery wnętrz zamku w Elsynorze" - napisał Brzoska w komentarzu do słuchowiska. „Z dużą nadzieją liczono również na wsparcie tą technologią nagrania kreacji postaci Ducha ojca Hamleta, występującej w kluczowych momentach tragedii”. ${ }^{19}$ Zapis wizualny materiału dźwiękowego sesji zrealizowanej z aktorami występującymi w słuchowisku na fotografii okna montażowego wygląda jak malarska abstrakcja.

W egzegezie tego obrazu Brzoska wymienia nazwy sprzętu, który zrewolucjonizował system pracy nad słuchowiskiem:

Do nagrań wykorzystano stół mikserski Yamaha DM 2000 skonfigurowany z systemem DAW Pro Tools 7 HD. U góry wizualizacji okna montażowego systemu Pro Tools widoczny jest zapis (w kolorze niebieskim) sygnału kanału lewego z mikrofonów Neumann SM 69 fet, generującego sygnał w lewym głośniku przednim. Zapis przebiegu fali dźwiękowej w kolorze czerwonym ilustruje sygnał generowany w głośniku przednim prawym. Kształt przebiegu fali dźwiękowej w kolorze zielonym, pomy niebieskim i czerwonym, to zapis kanału centralnego, który został sztucznie wygenerowany. Sygnał centralny otrzymano poprzez zsumowanie przednich kanałów. Wartość sygnału

18 B. Eno, Ambient, [w:] Kultura dźwięku. Teksty o muzyce nowoczesnej, wybór i red. C. Cox, D. Warner, przekł. M. Matuszkiewicz, Gdańsk 2010.

19 A. Brzoska, William Skakespeare, „Hamlet”, fragment niedrukowanej rozprawy doktorskiej obronionej w 2015 na Uniwersytecie Muzycznym Fryderyka Chopina w Warszawie. Tekst udostępniony mi przez Autora, któremu dziękuję za liczne wskazówki i wyjaśnienia. 


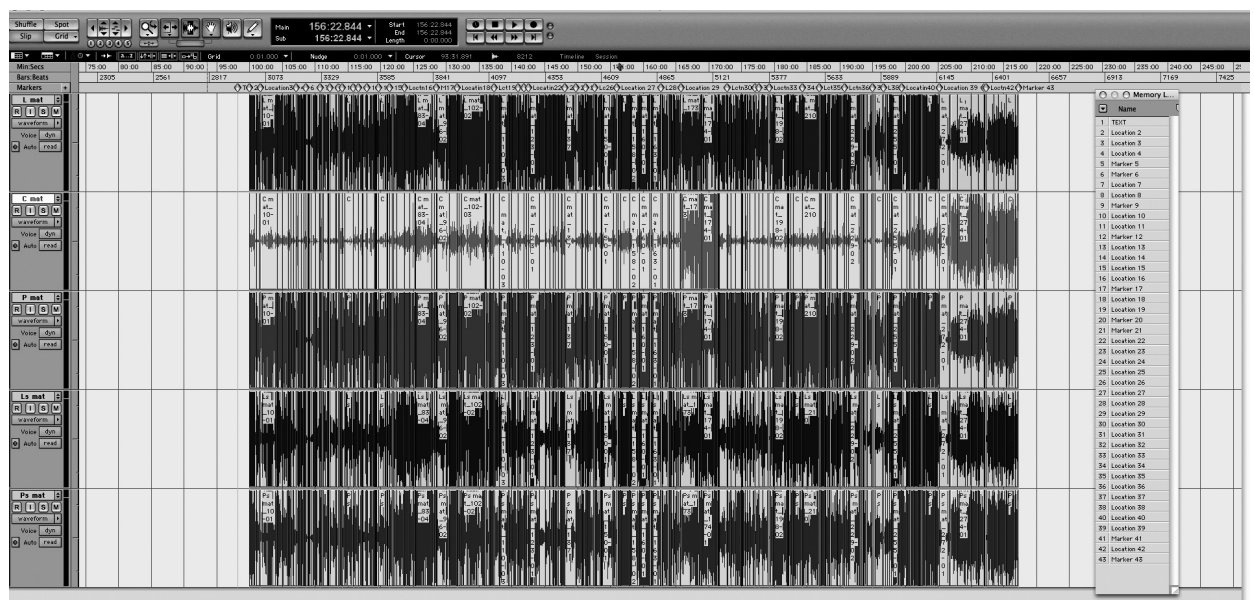

ustawiono eksperymentalnie na poziomie $-13.5 \mathrm{~dB}$. Pozostałe dwa przebiegi w kolorze fioletowym i ciemnym zielonym odzwierciedlają sygnały w kanałach tylnych. ${ }^{20}$

Zjawienie się Ducha sygnalizują fragmenty zaznaczone na wykresie jako Location 39 i Location 42 .

Są to kwestie Ducha, teksty ze sceny 5 aktu I na stronie 18 scenariusza i w 15 '25" słuchowiska, jak i nieartykułowane oddechy-tchnienia obecności Ducha do pierwszej sceny tragedii - wyjaśnia Brzoska. - Sygnał z mikrofonu Neumann SM 69, ustawionego w systemie stereofonicznym XY, rozprowadzono równomiernie między kanałami tak, aby Duch ojca Hamleta był usytuowany pośrodku między pięcioma głośnikami. Uzyskana w ten sposób wszechobecność Ducha w odsłuchowej panoramie przestrzennej podporządkowana została idei nierealności tej postaci w dramacie, $\mathrm{w}$ przeciwieństwie do realnych postaci usytuowanych w panoramie przed słuchaczem. ${ }^{21}$

Akustyczny opis sceny z Duchem wystarczy, by uchwycić podstawowy kierunek w rozwoju teatru radiowego. Staje się ono „dźwiękowiskiem”, jak w rozmowie z Barbarą Marcinik, poprzedzającą emisję Zimnego bufetu Zyty Rudzkiej, powiedział Andrzej Brzoska, czy ,,sound designem”, jak w tej samej audycji zaznaczył Dariusz Błaszczyk, reżyser. ${ }^{22}$ Słuchowisko staje się sztuką dźwięku przestrzennego, który tworzy iluzję bezpośredniego uczestnictwa w fikcyjnym świecie, analogicznie do systemu VR (Virtual Reality), sytuującego odbiorcę w środku rzeczywistości wykreowanej za pomocą przestrzennej animacji obrazu. Świat ten, za sprawą działających na zmysł słuchu oraz wyobraźnię obrazów dźwiękowych, sprawia wrażenie realnego, a różnica w charakterystyce dźwięku sygnalizuje nie tylko momentalną zmianę sytuacji dramatycznej, jak w słuchowisku

\footnotetext{
20 Ibidem.

21 Ibidem.

22 Premiera słuchowiska Zimny bufet na antenie Trzeciego Programu PR 12 I 2012 .
} 
tradycyjnym, ale rozszerzenie granic samej rzeczywistości. ${ }^{23}$ Nowe systemy akustyczne pozwalają usłyszeć więcej, lepiej, czyściej, tworzą hiperrealistyczne złudzenie przebywania w miejscach do tej pory niedostępnych i nadrealistyczne poczucie kontaktu z zaświatami. W binauralnej realizacji Smugi cienia Josepha Conrada (w reżyserii Dariusza Błaszczyka) odbiorca, poddawany akustycznej chłoście fal morskich jest w stanie wyobrazić sobie sztorm, choć pewnie nigdy nie przeżywał go na oceanie. Uwewnętrznia też śmiertelną chorobę i melancholię kapitana okrętu, choć fizyczne i metafizyczne odczucie dzielone z bohaterem było mu dotąd nieznane. Słuchowisko wielokanałowe wzmaga i pogłębia efekt, który jest fundamentalny dla odbioru dzieła radiowego, a mianowicie wspólnego nasłuchiwania, a co za tym idzie przeżywania świata razem z bohaterami. ${ }^{24}$ Pewność słuchacza Smugi cienia, że percypowany przez niego odgłos sztormu dla fikcyjnej postaci kapitana stanowi realną rzeczywistość, sprawia, że dochodzi między nimi do momentalnej symbiozy, niemożliwej lub bardzo trudnej w odbiorze dzieła literackiego, gdyż nie podejrzewamy, że napisana postać potrafi czytać swój napisany świat. Właśnie dlatego radiowa adaptacja literatury ma taką siłę oddziaływania, gdyż bezpośrednio włącza odbiorcę w subiektywne doświadczenia bohatera. Przestrzeń, którą za pomocą systemu 5.1 Brzoska wykreował w Kartotece Tadeusza Różewicza (w reżyserii Tomasza Mana) percypowana jest w następujący sposób:

Z każdej ze stron słuchacz jest otoczony sygnałami dźwiękowymi. Z prawej dobiega go przekształcony głos Chóru, który potęguje napięcie, z tyłu słyszy już odgłos gongów, z lewej strony sączy się niepokojące tykanie wskazówek zegara. Bohater mówi do niego z „centralnego” głośnika, a subwoofer - głośnik o niskich tonach - emituje tło w postaci agresywnej melodii ambient. ${ }^{25}$

Ta wyjątkowa konstrukcja przestrzenna świata dramatu Różewicza jest zarazem jego interpretacją, oto bowiem kwestie Chóru zostały zrealizowane jako dochodzący z prawej strony pogłos kwestii Bohatera. Powstaje wrażenie, jakby Chór był w Kartotece zbiorowym superego głównej postaci. Na tym jednak nie koniec, bo głos Chóru „potęguje napięcie” w odbiorcy, tykanie wskazówek zegara jest „niepokojące” dla słuchacza, a melodia ambient przez niego odczuwana jest jako ,agresywna”. W radiowej realizacji Kartoteki nasłuchujący (odbiorca) jest nasłuchiwanym (bohaterem). Właśnie ten efekt wydaje mi się najbardziej pociągający dla współczesnych autorów, którzy tworzą dziś nowy model dramatu subiektywnego - radiowy intencjonalnie lub tylko w potencji.

23 F. López, Stuchanie dogłębne i otaczająca nas materia dźwiękowa, [w:] Kultura dźwięku. Teksty o muzyce nowoczesnej, op. cit.

24 J. Limon, op. cit., s. 147-148.

25 J. Lastowiecki, op. cit., s. 65. 


\section{CZECZOT, CZYLI CYFROWY OBŁĘD}

Andy Krzysztofa Czeczota (prem. 2013) to utwór najbardziej reprezentatywny dla nowego kierunku, którym podąża dziś sztuka radiowa - i dramat współczesny. Jego bohaterem jest młody dźwiękowiec, który w domu na komputerze montuje dźwięk do filmu. Andrzej zakłada słuchawki i klika myszką (w słuchowisku jest to raczej dźwięk klawiatury komputera), uruchamiając na zmianę dwa pliki dźwiękowe. Pierwszym będą fragmenty autentycznego nagrania Moskwy-Pietuszek Wienedikta Jerofiejewa w legendarnym wykonaniu Romana Wilhelmiego, drugim - dźwiękowy zapis fikcyjnej rozmowy dwojga bohaterów na planie filmowym, montowany i „podbijamy” przez Andrzeja nastrojową muzyką. Bohater przełącza się z jednego pliku na drugi, dodatkowo powtarzając niektóre sekwencje ze ścieżki filmowej. W tym samym czasie odbiera telefon, by umówić się z producentem, i rozmawia z matką, która krzyczy z sąsiedniego pokoju, uruchamia telewizor, a w pewnej chwili wchodzi do pokoju syna $\mathrm{z}$ nadzieją wyrwania go z wirtualnej rzeczywistości.

Andy to chyba najlepszy przykład dramatu subiektywnego w epoce mediów cyfrowych. Bohater tego słuchowiska funkcjonuje w kilku planach akustycznych, nad niektórymi panując, innym podlegając, przy czym w pewnym momencie dochodzi do ich zaskakującego pomieszania. Słuchając zrzędzącej matki, Andrzej przyspiesza i zniekształca jej głos, a kiedy powtórnie odbierze telefon, usłyszy w nim - Romana Wilhelmiego, który odzywa się do niego słowami z powieści Jerofiejewa. W ten sposób ujawnia się obłęd bohatera, który będzie się pogłębiał i doprowadzi do zabójstwa matki - jak się okaże, wyimaginowanego. W słuchowisku dochodzi do momentalnych złożeń akustycznych i dźwiękowych przebitek - to Andrzej „steruje biegiem wydarzeń”, a czynność przełączania z jednego planu akustycznego w drugi staje się metaforą kondycji ludzi współczesnych. W pewnym momencie Andrzej zmienia tożsamość i staje się Andym. Odtąd będzie rozmawiał z Romanem Wilhelmim i bohaterką montowanego filmu, Magdą, z którą umówi się i spotka, przeżywając sensacyjną historię. Dzięki systemowi dźwięku przestrzennego doświadczamy obłędu bohatera, a literacki scenariusz staje się precyzyjną partyturą tego eksperymentu. Jego lektura bywa równie zaskakująca, jak odbiór słuchowiska. W didaskaliach Czeczot zapisuje nagle pytanie: „Co widzi Andrzej?”26 i nie odpowiada na nie, jak gdyby nie panował nad swoim bohaterem i akcją, która mu podlega.

Nieco inaczej system 5.1 wykorzystał Czeczot w swoim wcześniejszym słuchowisku Dublin one way (prem. 2008), które też zrealizował na podstawie własnego tekstu. Jego bohaterem jest Kris, współczesny emigrant zarobkowy z Polski. Mężczyzna leci samolotem ze Szczecina do Dublina, potem instaluje się w mieszkanku z innymi emigrantami, szuka pracy, rozmawia z żoną przez telefon, słucha radia i uczy się angielskiego $\mathrm{w}$ internecie. Wiemy to wszystko dzięki precyzyjnie

\footnotetext{
26 K. Czeczot, Andy, tekst niedrukowany, udostępniony mi przez Autora.
} 
skonstruowanej ścieżce dźwiękowej, która w pięciu kanałach zbiera głosy mieszkańców Dublina, odgłosy tego zatłoczonego miasta i wiele innych sygnałów obecności i aktywności bohatera. Kris prawie wcale się nie odzywa, a jeśli to robi, jego głos z ledwością przebija się przez inne dźwięki, jest przez nie zagłuszany, znika w wielkomiejskim zgiełku. Nie tyle więc słuchamy bohatera, ile go podsłuchujemy, gdy nieporadną angielszczyzną pyta o pracę lub żebrze w metrze. Jednocześnie wychwytujemy wszystko, co słyszy sam Kris, zanurzając się w jego własną fonosferę emigranta. Także tutaj Czeczot subiektywizuje rzeczywistość, ale jednocześnie odbiera swojemu bohaterowi wyjątkowość, sprawczość, słowem - podmiotowość. Reprezentacją Krisa jest zanikający głos, stanowiący ledwie cząstkę fali dźwięków, która go porywa i unosi. Ulotność jego egzystencji, przypadkowość zdarzeń, których doświadcza, przeciętność biografii nie przekreślają jednak osobistego wymiaru tej historii. $Z$ dźwiękowych drobin, które dobiegają do nas z różnych stron - tak jak dobiegają do Krisa, rekonstruujemy niepowodzenia bohatera, jego napięcie spowodowane brakiem pracy i wyrzutami żony, potem chwile satysfakcji, nawet szczęścia. Moment metafizyczny, kiedy Krisowi zdaje się, że lektor radiowy i nauczyciel angielskiego mówią tylko do niego, pozwala doświadczyć nie tyle choroby psychicznej młodego mężczyzny - jak w Andym, ile samotności tego ledwie zauważalnego bohatera naszych czasów.

\section{MAN, CZYLI AUDIOTEKSTY LOSU}

Krzysztof Czeczot pisze dramaty radiowe nowej generacji, a inspiracją dla jego twórczości jest nowa technologia - wykorzystywana do realizacji słuchowisk, a zarazem metaforyzowana jako dramatyczna matryca świadomości ludzi współczesnych. Inaczej Tomasz Man, który podstawą swoich autorskich słuchowisk uczynił teksty o kształcie rozpisanego na głosy poematu, a technologię zaprzągł w konstrukcję doświadczenia o wymiarze tragicznym. Man nie stosuje didaskaliów, które w jakikolwiek sposób określałyby przestrzeń akustyczną jego sztuk. Mimo to nazywa je ,audiotekstami”, zapisane słowo i potencjalny dźwięk, stawiając na tym samym poziomie. Autor często pracuje w formule postdramatycznej, jego postacie są narratorami własnych historii, które niekiedy zamieniają się w historię wspólną. „Audiotekstami” rządzi reguła retrospekcji, podlegająca nagłym komplikacjom i zaburzeniom, jak w Mojej ABBIE z 2011.

Rzeczywistość w tym najbardziej znanym słuchowisku Mana multiplikuje się. W jej warstwie współczesnej fikcyjny Reżyser postanawia zainscenizować wielkie telewizyjne show, będące powtórką $\mathrm{z}$ historycznej wizyty $\mathrm{w}$ Polsce szwedzkiego zespołu ABBA, który w telewizyjnym programie Studio 2 wystąpił 13 października 1976. Osią programu artysta pragnie uczynić spotkanie z ABBĄ dawnej fanki zespołu, którą współcześnie miałaby zastąpić jej córka. Fanka w młodości próbowała dostać się do Szwecji szybowcem, który się rozbił. Reżyser oczywiście pragnąłby powtórzyć także to spektakularne wydarzenie, 
ale kobieta stara się do tego nie dopuścić. Próbuje ostrzec córkę, jednak nie wprost, ale na zasadzie wewnętrznej podróży w przeszłość po trajektorii własnego życia naznaczonego lotniczą katastrofą. Oto jak opisuje jej eksperyment autor słuchowiska:

Bohaterka „przemienia w głowie” Reżysera w Chłopaka, z którym też śpiewała piosenki ABBY. Córkę na samą siebie z czasów, gdy była nastolatką, a Ojca utożsamia z Mężem. Jej życie jest pewną „kalką” rodzinnych stosunków. Trafia na moment, kiedy jej narzeczony pakuje się. Za chwilę ma wyjść z domu i udać się na górę szybowcową, skąd razem mają wylecieć szybowcem. Chłopak jest zaskoczony wtargnięciem jakiejś ,,pani” do jego pokoju. Kobieta stara się przekonać, żeby nie lecieli. Chłopak podejrzewa ją, że jest z Urzędu Bezpieczeństwa. Zostaje oskarżona o inwigilację. Nie udało się jej nakłonić do rezygnacji. Nagle „przenosi się” do Dziewczyny. Jest to ona sama, ale trzydzieści lat młodsza. Ją również próbuje przekonać do rezygnacji z ucieczki na szybowcu. Ostrzega ją, że lot zakończy się tragicznie. Argumenty nie trafiają do przekonania Dziewczyny. Potrzeba ucieczki z ukochanym bierze górę nad rozsądkiem. Ostatnim człowiekiem, który może zabronić lotu szybowcem jej ojciec. W spotkaniu z ojcem [kobieta] udaje swoją matkę. Próbuje namówić go na interwencję. Ojciec jest zainteresowany „tą samą a jednak inną” żoną. „Powrót do przeszłości” nie przynosi zakładanych rezultatów. Projekcja wyobrażeń bohaterki o tym, co mogłaby powiedzieć, i jak postąpić, co zmienić, gdyby miała szansę „zawrócić czas”, skończyła się fiaskiem. ${ }^{27}$

Fanka ABBY, choć po szybowcowej katastrofie przez pół roku leżała w śpiączce, zachowała miłość do szwedzkiego zespołu, który pozostał dla niej symbolem wolności, i zaraziła nią Córkę. Dlatego teraz obawia się o jej życie, a Man tę obawę dramatyzuje jako momentalne nałożenie czasów i tożsamości, możliwe do przeprowadzenia dzięki specjalnej kompozycji głosów w słuchowisku przestrzennym. Autor zapisuje je w postaci poetyckich monologów, ale w akustycznej realizacji tekstu komponuje je tak, jakby malował obraz, na który składa się wiele ,plam dźwiękowych”. Każda z nich to oddzielne pole działania bohaterów, którzy nie tylko mówią, ale też odbierają telefon i wykonują różne czynności. Ta wielokanałowa przestrzeń jest także miejscem metamorfozy bohaterów. Gdy kobieta śpiewa przebój ABBY, najpierw jej głos brzmi bardzo intymnie, ale po chwili nabiera koncertowej barwy, a zmiana ta sygnalizuje fikcyjną, dokonująca się tylko w świadomości bohaterki realizację jej marzeń, aby zaśpiewać ze sławnymi Szwedami. Głosy mają różną specyfikę, która wskazuje na charakter postaci i ich stan wewnętrzny, ale też czas i okoliczności wydarzeń, które są płynne i dla słuchacza stanowią zagadkę. Niekiedy między postaciami zawiązuje się dialog, ale barwa ich głosów się nie zmienia i wtedy orientujemy się, na ile realna jest ta rozmowa, a także z czego wynika i co znaczy kontakt bohaterów. W tekście dramatu Mana nic zmiany tej nie sygnalizuje i nie wyłapiemy jej, jeżeli nie zestroimy

27 T. Man, Muzyczność stuchowiska. Analiza czterech stuchowisk autorskich przygotowanych w Teatrze Polskiego Radia. Niewydana rozprawa habilitacyjna złożona w bibliotece Wyższej Szkoły Teatralnej im. Ludwika Solskiego w Krakowie, filia we Wrocławiu. 
się z postacią na poziomie jej afektu. Natomiast w słuchowisku afekt ten nabiera brzmienia, staje się elementem przestrzennego kolażu dźwiękowego, który kontemplujemy od wewnątrz, doświadczając wraz z bohaterką tragicznego rozczarowania - losu nie da się zmienić, a katastrofy uniknąć.

Dźwięki naturalne, spreparowane i muzyczne zajmują w Mojej ABBIE tę samą pozycję, co głosy postaci, choć ich zakres akustyczny może być większy, a brzmienie potężniejsze. „Przy pisaniu tekstu Moja ABBA brałem pod uwagę rytm, tonacje i teksty piosenek zespołu" - tłumaczy autor. ${ }^{28} \mathrm{~W}$ słuchowisku komponuje kilka równoległych ścieżek dźwiękowych i dźwiękowych obrazów. Słyszymy koncert ABBY w kiepskim, butlegowym nagraniu, urywki audycji telewizyjnych na temat zespołu, ale też odgłosy koncertowej publiczności i manifestacje uliczne. Dźwięk o specjalnym charakterze jest groźny, niepokojący i zagarniający całą przestrzeń - to odgłos powietrza uderzającego w ścianki szybowca, który brzmi jak memento. Dźwiękowy obraz nie pozostaje statyczny, zasadą jego funkcjonowania jest narastająca dynamika akustycznych ambientów. Dźwiękowa historia kobiety zafascynowanej piosenkami ABBY przechodzi w zgiełk, by nagle zapaść w ciszę, intymne zwierzenie, ciche nucenie przeboju Thank you for a music, które brzmi jak osobiste wyznanie samego autora.

Linearny zapis ,audiodramatu" Mana wymaga wyobraźni przestrzennej i dźwiękowej, a jego lektura jest równie fascynująca jak odbiór słuchowiska. Man nie stosuje zapisów typowych dla scenariusza radiowego, koncentrując się na poetycko skomponowanych słowach, a nie fonosferze, która stanowi miejsce puste i przeznaczone do wypełnienia. Nie objaśnia też zmian w czasowo-przestrzennych w dramacie, charakteru doświadczeń jego bohaterów, różnic w statusie ontologicznym postaci. Zagadkę tych nagłych transformacji rozwiązują tylko aluzje tekstowe, które są zarazem podpowiedzią realizacyjną. Autor wrzuca nas swoimi tekstami w sam środek pozornie płaskiego świata, który dzięki uważnej lekturze zyskuje nowy wymiar przestrzenny i czasowy z możliwością multiplikacji rzeczywistości w planie fizycznym i psychicznym bohaterów. Mimo dzielącej ich odległości i czasu, który upłynął lub jeszcze nie nadszedł, wszyscy tu ze sobą rozmawiają na zasadzie jednoczesności wyższego rzędu, którą ostatecznie jest autorska świadomość.

\section{BIELIŃSKI, CZYLI NASŁUCHIWANIE ZAŚWIATÓW}

Zasada ta rządzi też światem sztuki Mariusza Bielińskiego Księga psa, na podstawie której powstało jedno z najbardziej oryginalnych słuchowisk Sceny Teatralnej Trójki (reżyseria Waldemar Modestowicz, realizacja akustyczna Tomasz Perkowski, prem. 2009). Księga psa to dramat minimalny. Ciąg niczym nieoznaczonych, jednowersowych kwestii ledwie domyślnych postaci autor podzielił na sześćdziesiąt dziewięć części różnej długości, które odpowiadają scenom.

28 Ibidem. 
Krótkie, zwięzłe, eliptyczne, niekiedy złożone z pojedynczych wyrazów - nie tyle reprezentują tu jakąś rzeczywistości, ile dają do niej dostęp. Sens, styl, forma gramatyczna słów pozwala się zorientować, że głównymi bohaterami dramatu są mężczyzna i kobieta, całkowicie skoncentrowani na chorobie nowotworowej ich ukochanego psa. $\mathrm{Z}$ ich wypowiedzi domyślamy się też, że akcja utworu rozgrywa się w kilku miejscach: mieszkaniu, gabinecie weterynarza, w parku, piwnicy, samochodzie i trwa niecałe dwa tygodnie, podczas których pies traci siły, umiera i zostaje pochowany. Mężczyzna pełni też rolę narratora, ale jego relacja ogranicza się tylko do jednego planu dramatycznego. A jest ich w Księdze psa kilka, obok akcji i szczątkowej narracji, Bieliński uruchamia bowiem przynajmniej trzy równoległe kanały komunikacyjne o zagadkowym kształcie i charakterze. Na ślad pierwszego natrafiamy już w drugiej części utworu:

I co panie doktorze?

Porozmawiamy za chwilę.

Siadamy na ławie pod ścianą.

Leżę. ${ }^{29}$

Pierwsza linijka tego polilogu to kwestia mężczyzny, drugą wypowiada weterynarz, trzecią znowu mężczyzna (jako narrator), czwartą natomiast - pies, a dobiega ona z zupełnie innego planu dramatycznego, który w tekście w ogóle nie zostaje zaznaczony. Jest to plan nadrealny, a zarazem wewnętrzny, pies bowiem nie tyle mówi ludzkim głosem, ile nim myśli. Kolejny plan należy do mężczyzny, który w dramacie nie tylko uczestniczy w akcji i relacjonuje wypadki, ale też medytuje nad zdarzeniami, a czyni to w sposób zaskakujący, w swojej refleksji łącząc umierającego psa z samym Bogiem:

Mój pies

I mój Bóg

Nic nie wiedzą

O śmierci

Więc jak mogliby

Umrzeć

Przecież to niedorzeczne ${ }^{30}$

Tego rodzaju medytacja, wewnętrzna lub wypowiedziana w samotności, natychmiast otwiera kolejny plan dramatu, a jest nim monolog Boga, który dobiega do nas z zaświatów głosem przypominającym ten, który zapisał prorok w Księdze Powtórzonego Prawa:

Pomyślałem pies

I stał się

Wielki

29 M. Bieliński, Księga psa, tekst niedrukowany, korzystam z wersji udostępnionej przez Autora.

30 Ibidem. 


\begin{abstract}
$\mathrm{Z}$ obślinionymi faflunami
Niedowidzący

No taki

Pies

Ponad osiemdziesiąt kilo

Będą kłopoty ze stawami

I powiedziałem

Jesteś psem

Choć coś mi szeptało

Po co to wszystko

Pies

Przecież nie będę mu tego tłumaczył

Jam jest Pan Bóg twój

Chyba nie zrozumiał

Pobiegł i obsikał drzewo ${ }^{31}$
\end{abstract}

Mamy jeszcze plan retrospekcji, kiedy pies Marian cieszył swoich właścicieli witalnością, oraz wewnętrznych niby-rozmów człowieka z chorym zwierzęciem. Wszystkie Bieliński komponuje na sposób linearny, w istocie jednak tekst Księgi psa jest projektem przestrzennym i choć nie został on napisany jako scenariusz słuchowiska, właśnie w takiej formule realizacyjnej staje się zrozumiały i przejmujący.

Słuchowisko w swojej warstwie realistycznej tworzy w słuchaczach złudzenie uczestnictwa w terapii psa, mozole opieki nad chorym zwierzęciem, jego transportowaniu, grzebaniu. Natomiast wymiar nadrealny audycji, sygnalizowany modulacją aktorskich głosów, daje mu poczucie przekraczania granic ludzkiego doświadczenia i to w dwóch niedostępnych człowiekowi kierunkach: zwierzęcym i boskim. Podmiotem nasłuchującym jest mężczyzna, który prowadzi wewnętrzny dialog i z psem, i z Bogiem. Bieliński zrównał ich w tej odważnej medytacji teologicznej o sensie śmierci, co podchwycił Waldemar Modestowicz, partie umierającego zwierzęcia i jego Stwórcy powierzając jednemu aktorowi obdarzonemu wyjątkową głębią głosu - Mariuszowi Benoit. Głosom, w osobnym kanale, towarzyszą przejmujące odgłosy: sapanie przestraszonego, skomlenie cierpiącego, wreszcie westchnienie umierającego zwierzęcia. Tkwiąc w samym środku tego obrazu dźwiękowego, uczestniczymy $\mathrm{w}$ wielogłosowym misterium śmierci, w którym empatia wobec cierpiącego zwierzęcia silniej niż słowa oskarża niemiłosiernego Boga. W finale słyszymy trawestację Hymnu o miłości z Pierwszego listu do Koryntian św. Pawła:

$31 \quad$ Ibidem. 
„Śmierć nigdy nie ustaje” - mówi Bóg, a niepogodzony ze śmiercią bohater opowiada sen o psim zmartwychwstaniu:

Widziałem go

Biegł po łące

Zielonej $^{32}$

\section{KONKLUZJA}

Księga psa uświadamia, że istotą dramaturgii o radiowym genotypie jest próba poszerzania i dynamizowania świadomości odbiorców poprzez uwewnętrznienie głosów postaci egzystujących w granicznej sferze ,pomiędzy”: konkretnym i abstrakcyjnym, realnym i nadrealnym, fizycznym i metafizycznym, immanentnym $\mathrm{i}$ transcendentnym. Wizyta $\mathrm{w}$ ciele chłopca pogrążonego w śpiączce ( $W$ środku słońca gromadzi się popiót Artura Pałygi), myślany dialog sparaliżowanej kobiety z mówiącymi do niej członkami rodziny (Ciało moje Marka Pruchniewskiego), spotkanie z nieżyjącą matką w jej trzech fantomowych postaciach (Zimny bufet Zyty Rudzkiej), uwięzienie w wilczych wnętrznościach ( $W$ brzuchu wilka Roberta Jarosza), konfrontacja mordercy z „duchem powrotnikiem” zabitego chłopaka (Idę, tylko zimno mi w stopy Tomasza Mana) to tylko niektóre $\mathrm{z}$ dramatycznych sytuacji projektowanych jako subiektywne doświadczenie odbiorcy zamkniętego w dźwiękowej kapsule. Dramaturgia o radiowym genotypie poszerza granice poznania, otwiera nieznane kanały komunikacji, czyni dostęp do przeczuwanego i rejestruje nieuchwytne. A wszystko to za pomocą słów, które czekają na wrażliwego czytelnika - i utalentowanego realizatora, wyposażonego w wyobraźnię i nowe technologie. To dzięki nim penetrujemy w nowych dramatach zamienianych w słuchowiska niedostępne terytoria - fizyczne, psychiczne i duchowe, niekiedy nawet spotykając zmarłych. Zarejestrowany głos osoby, która odeszła, nie jest bowiem jej dokumentalną reprezentacją, jak fotografia czy film ${ }^{33}$, ale utrwaloną realnością, możliwą do przy(wy)wołania za pomocą technologicznego medium. Głos Romana Wilhelmiego zabrzmiał w Andym Czeczota tak, jakby zmarły przed wielu lat aktor osobiście wziął udział w nagraniu. $Z$ kolei w słuchowisku 0_2_0 Krzysztofa Bizio (prem. 2018) do zanurzonych w radiowej fonosferze słuchaczy powraca Piotr Łazarkiewicz z jego charakterystyczną dykcją. Autor zapisuje słowa reżysera, dźwiękowiec - sięgając po radiowe dokumenty - przywraca im nowe, bardziej subtelne, bo tylko brzmiące ciało, a potem włącza je w dramat fikcyjnej postaci, która w słuchowisku nowej generacji staje się medium dla zewnętrznych i wewnętrznych doświadczeń odbiorcy. Dramaturgia o radiowym genotypie to projekt metafizyczny.

\footnotetext{
32 Ibidem.

33 H. Lethen, Cień fotografa. Obrazy i rzeczywistość, przekł. E. Kalinowska, Kraków 2016.
} 